\title{
Science in Industry*
}

$\mathrm{T}$ HE twenty-third report of the Department of Scientific and Industrial Research, which covers the period October 1, 1937-September 30, 1938, includes the report of the Committee of the Privy Council signed by Lord Runciman, and the longer report of the Advisory Council over Lord Riverdale's signature, together with summaries of the work of the National Physical Laboratory and other research stations and research boards and brief accounts of the work of the various research associations. Like previous reports of the Department, the present one gives a most impressive picture of the immense contribution which the work of the Department is making not only to almost every type of industry but also in all aspects of national life.

The expenditure of the Department in 1937-38 was $£ 872,127$ gross or $£ 637,200$ net as against $£ 583,230$ net in 1936-37. As usual, the largest single item of expenditure was $£ 110,907$ on the National Physical Laboratory, compared with $£ 105,589$ in $1936-37$, the gross expenditure of $£ 252,209$ including the cost of work at the Laboratory for the Food Investigation Board, the Radio Research Board, the Road Research Board and other research boards of the Department. Against this gross total, receipts amounted to $£ 141,302$, of which $£ 69,822$ represents fees from industry for paid work. The total receipts from industry, including contributions to co-operative research, amounted to $£ 98,452$ as against $£ 106,250$ in $1936-37$, while a

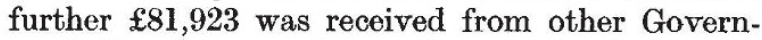
ment Departments for services rendered, $£ 33,337$ from the Road Fund for the road research and $£ 6,282$ from the Empire over-seas for food investigation. Expenditure on fuel research was $£ 103,240$ gross or $£ 94,782$ net, on building and road research $£ 97,382$ gross or $£ 40,626$ net, on the Chemical Research Laboratory $£ 23,340$ net, on food investigation $£ 54,709$ gross or $£ 45,307$ net, on forest products research $£ 38,841$ net, on water pollution research $£ 9,134$ gross or $£ 5,421$ net and on the Geo-

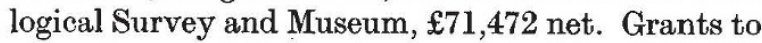
research associations, etc., amounted to $£ 148,282$, as against $£ 120,510$ in $1936-37$ and $£ 108,951$ in 1935-36, and the report notes the formation of a new research association, the British Coal Utilization Research Association, bringing the number of such associations to twenty-three.

The report refers to the dissolution of the

* Department of Scientific and Industrial Research. Report for the year 1937-38. (Cmd. 5927.) Pp. iv +203. (London: H.M. Stationery Office, 1939.) $3 s$. net.
Radium Beam Therapy Research Board, but the investigation for which it was responsible will be continued under the general control of the Committee of the Privy Council for Medical Research, and the Department will continue to keep in touch with the physical investigations included in the general programme of research. The Welding Panel of the Steel Structures Research Committee has also been discharged during the year upon the completion of some outstanding work, as well as the Standing Conference on Timber Utilization.

\section{Food}

A large part of the report of the Advisory Council is devoted to a review of progress in food investigation in recent years. The food investigation organization of the Department has now completed twenty years of work, and under present conditions the work that was begun in the face of a serious shortage of food has lost nothing of the national importance which was attached to it in 1937. Indeed, questions of storage no less than of transport of food are now regarded as an essential, if not a decisive, element in a national policy of defence, and the importance of this phase of the Department's work to the whole community need not be further stressed. From the start, this work has been concerned to avoid loss and wastage, during handling and storage, in the supply of foodstuffs and to ensure that this supply is made available in the best condition. Throughout the period, the need of the consumer has been the governing consideration, and the Food Investigation Board has found solutions for all three of the great problems which confronted it at the start.

The problem of the preservation of fruit, much of which responds badly to ordinary cold storage, has been solved by the development of 'gasstorage', a new method in which the ventilation of cooled stores is adjusted so that their atmosphere contains just the right amount of carbon dioxide. Ten years ago there were no gas-stores. To-day they provide three million cubic feet of storage, and this is only a beginning. Again, up to 1933, Australia and New Zealand still had to send their beef to Great Britain in the frozen state, when it is not a satisfactory product. Now it has been shown that chilled beef can be preserved for long periods in special chambers enriched with carbon dioxide, and in 1937 Australia and New Zealand sent us some three quarters of a million hundredweight of chilled beef carried in this way. 
The third problem, that of handling and preserving fish, which is highly perishable, and as ordinarily handled and stowed cannot be kept really fresh for more than ten to twelve days, has also been solved by the development at the Torry Research Station of brine freezing and cold storage at a low temperature. By the new methods lemon soles have been stored for two years and were in excellent condition at the end of that period. Success in these fields has been achieved, as the Advisory Council's report insists, by building up, however slowly, a science of the storage and transport of food, and the achievements of the Department in regard to food investigation are a remarkable tribute to the service which science can render in everyday life.

The present report refers to other work in progress, including investigations of the changes in muscle post mortem, the rancidity of edible fats, the causes of rotting of eggs, the factors which affect the composition and structure of the fatty and muscular tissues of the pig and the quality of the bacon which depends upon them, the distribution of vitamin A in fish, the cold storage of herrings, the spoilage of haddock in crushed ice and chemical indexes of freshness. The work on gas-storage has covered the storage of Cox's Orange Pippin apples and English-grown William pears, and studies in the resistance of apples to fungal invasion have also been continued, as well as on the experimental storage of broccoli, the freezing of vegetables for preservation, the thermal properties of butter, and on the relation between the rate of formation of hydrogen swells in cans filled with various fruits and the rate of corrosion by acid of the steel base of the tin-plate used in their manufacture. The Advisory Council has now further invited the Board to review the whole field of research into the processing of foodstuffs and to submit proposals for embracing under its scientific supervision work in this field which is desirable in the national interest.

A further special aspect of food research is stressed in the report of the Advisory Councilthat of preventing the loss of stored foodstuffs by attack. The destruction of grain by weevil and other pests is estimated to cause a loss in Great Britain of $£ 500,000$ annually, a figure which might easily be exceeded if the problem is left unsolved while the plans for storing grain in the national defence policy are developed. The Department has now accepted the responsibility for a survey of the infestation of grain and grain products in this country, covering all stages in the handling of the grain, from harvesting or arrival at the port to delivery to the consumer. A standing conference, representing all the industrial interests desiring to co-operate, has been established as a consultative body, on which brewers, corn merchants, flour millers, railway companies, cattle food trades, wharfingers, maltsters, lightermen, farmers and port authorities are represented, and the work was commenced in May by the staff of the Stored Products Laboratory at the Imperial College of Science and Technology, London, under Prof. J. W. Munro.

Besides the work of the Food Investigation Board, several of the research associations have made important contributions to our knowledge of foodstuffs and dietary problems. The Research Association of British Flour Millers, for example, has been responsible for important investigations into the nutritive value of bread which have emphasized the importance of bread and lard, or bread and butter in the dietary, and other work has been concerned with developing the instrument for measuring and recording graphically the baking quality of flour and the conditioning of wheat prior to milling.

Investigations carried out by the Research Association for the Cocoa, Chocolate, Sugar Confectionery and Jam Trades, on the properties of different white sugars used for certain confectionery processes, have indicated that the differences in behaviour were due to differences in minute quantities of impurities in the sugars. This discovery has led to new operating methods and also substantial savings of sugar, and further investigations of the same type have shown that complaints by employees that certain brands of sugar were unsatisfactory for a specific purpose were justified. Other investigations of the Association have advanced our knowledge of the properties of pectin compounds and afforded a new explanation of the phenomena of jelly formation. The Food Manufacturers' Research Association has obtained important results in bacteriological investigations on the curing of bacon and hams, as well as on the canning of meat and on the corrosion and perforation of the cans and the methods of lacquering the cans to prevent corrosion.

\section{LIGHT INDUSTRIES}

Other research associations are making equally important contributions in the field of clothing. The Boot, Shoe and Allied Trades' Research Association, continuing its work on occupational footwear, has made good progress in research to discover the best styles of footwear for various kinds of employment, and other investigations commenced during the year deal with the influence of heel height upon poise. The results obtained in this intrusion on the thorny problem of the effect of high-heeled shoes on health suggested that the best height is governed by a woman's occupation 
and the customary poise which her occupation may impose.

The Wool Industries Research Association has continued its investigation on shrinkage-resistant wool, including an entirely new type of reaction, which consists in the use of proteolytic enzymes of the type of papain whose activity can be controlled chemically and which appear to have specific action on certain regions of the wool fibre. Other work has been concerned with the rubberization process, the measurement of shrinkage in fabrics due to milling and laundering, and the fastness of dyed materials to washing. The Linen Industry Research Association has continued its work in relating yarn and fabric properties, and on degradation and fading of fabrics used for casements and awnings; it is now possible to select vat dyes which decrease the chances of premature deterioration. Similarly the British Launderers Research Association's investigations have thrown much light on the mechanics of the first part of the washing process, and its bacteriological investigations have shown that goods washed and finished in the laundry are much more nearly sterile than goods washed and dried in the home.

The British Leather Manufacturers' Research Association has continued its investigations on the chemical basis of the finishing process, and an X-ray plant has been installed for studying the effect of the various tanning processes on the internal structure of the fibres. The physical and microscopical characteristics of chrome calf and of glacé kid have been examined with the object of obtaining better quality leather for boot and shoe uppers. The Research Association of British Rubber Manufacturers has devised a method by which the ordinary dry raw rubber of commerce can be reduced to a fine granular condition by a simple process requiring no special machinery beyond that ordinarily used in rubber manufacture, while its investigations on ebonite have aimed at obtaining a material better suited to modern needs.

The Printing and Allied Trades Research Association has now passed a year in its new laboratories, and has completed an investigation into the causes of the tarnishing of bronze printing used in the decoration of goods for confectionery and eigarette wrappers, which has traced the tarnishing to minute quantities of compounds containing sulphur in the paper, ink or adhesives used. A method of determining these small quantities of sulphur has been devised which enables the materials to be tested as to their suitability. The Research Association of British Paint, Colour and Varnish Manufacturers has completed investigations on the surface characteristics of pigment particles and their physical form in relation to their behaviour in paint, as well as on the role of oxygen in the formation of films by drying oils and varnishes.

\section{HEAVy INDUSTRIES}

It is impossible in the space at our disposal to refer to the work of all the research associations even, but three more examples can be given to illustrate how their activities contribute to almost every side of the amenities no less than of the necessities of society. The Electrical and Allied Industries Research Association has been giving attention to problems arising in making electricity supply more readily available to farms and in its more efficient application to agriculture and horticulture, as well as to the prevention of interference with broadcasting, the study of surge phenomena with the view of minimizing damage and inconvenience due to lightning, and the design of flameproof mining switchgear. The British Non-Ferrous Metals Research Association has investigated the behaviour of copper pipes and galvanized tanks in the domestic water system, while the work of the Cast Iron Research Association has led to the development of cast iron with a tensile strength of more than sixty tons per square inch, although a few years ago a strength of more than about twelve tons per square inch could not be obtained.

\section{Fuel}

Investigations carried out by the Automobile Research Committee on the factors which affect the starting of automobile engines in the cold have shown that by an apparently minor modification in engine design the power of the engine to overcome its own internal friction can, under certain conditions, be doubled. Further investigations under this Committee have dealt with the tendency of piston rings to stick in their grooves, due to the formation of gum in the lubricating oil under the high-temperature conditions, and a comparatively simple test has been developed for measuring the gum-forming propensities of lubricants. Besides its chemical and physical survey of the national coal resources, the Fuel Research Board has dealt with the preparation of coal for the market and has continued its work on the hydrogenation of coal and tars to oils and motor-spirits and on the synthesis of hydrocarbons and the production of lubricating oils.

\section{National Physical Laboratory}

Turning now to the activities of the National Physical Laboratory, special stress is laid on the work carried out in regard to the testing of the electrical switch gear. The development of the 
grid has entailed transmission of large amounts of power at high voltages and has called for much patient research into means for its control. An important problem is the provision of switchgear designed to ensure the safety of operators and to protect electrical equipment against accident. No public station is available for examining the behaviour of new designs and circuits reproducing serious conditions of overload which sometimes occur in service.

While the Department was considering the possibility of erecting such a station, a proposal for co-operation was made by the association of manufacturers owning the existing stations. It offered to open its stations to tests for any British manufacturer, with a guarantee that testing-time would be available at the stations as a whole equivalent to the full time of a Government station of the type contemplated. Moreover, it agreed to accept a measure of supervision of the tests by the Department which would make possible the issue of a National Physical Laboratory certificate for switchgear which passed agreed standards of performance. Such standards have already been drawn up by the British Standards Institution to cover circuit breakers of medium and high capacity. The negotiations necessary to accept this offer have been completed and the National Physical Laboratory is now prepared to accept crders for testing electrical switchgear designed to operate at voltages between 3,300 and 11,000 volts and up to capacities not exceeding $250,000 \mathrm{kva}$. for compliance with the provisions laid down in the appropriate British Standards specification.

Much important work has also been carried out at the Laboratory on the reduction of noise, including an investigation into the noise of motor-horns, while investigations are in progress for the Institution of Automobile Engineers on the silencing of motor-cycles and the reduction of drumming in motor-car panels, as well as on the lessening of noise in tube trains. Other work has been carried out in association with the Building Research Station on the transmission of sound through walls, floors and building materials, while in another department problems of illumination involving street lighting and the effect of illumination by the headlights of a motor-car under both dry and wet conditions have been investigated. An interesting side investigation has been that of the possibility of controlling the movement of eels in water by electrical fields, undertaken by the Laboratory at the request of the Ministry of Finance for Northern Ireland, instigated by the necessity of devising some alternative form of fishing owing to the obstruction to the discharge of water by an existing eel weir in a large drainage scheme on the lower
Bann River. In this investigation the possibility of diverting eels electrically on a small scale appears to have been established.

\section{Building and Road Research}

The Building Research Board, with its research station at Watford, has continued its work on the efficiency of buildings from the point of view of the user, and has been associated with the investigation on the strength of existing road bridges being undertaken for the Ministry of Trar sport.

The Road Research Board has continued its studies on the problem of skidding and on bituminous surfacings, in which the behaviour of the surfacings on a public highway is being compared directly with their behaviour on one of the road machines at the laboratory. It has also been associated with the Timber Development Association in investigations of the properties of wood block paving. A special investigation is being carried out for the British Rubber Producers Research Association on the effect of incorporating chlorinated rubber with tar.

\section{Miscellaneous}

The Forest Products Research Board has been responsible for investigations ranging over the fire resistance of timber, the control of the death watch beetle or the lyctus powder post bcetle, glues and adhesives and the chemistry of wood. The Water Pollution Research Board has covered the base exchange process of water softening, the exchange properties of synthetic resins, the contamination of water by lead and the problems arising in the treatment and disposal of dairy waste water. Attention has also been given to the physical, chemical and biological changes which occur in the purification of domestic sewage by the active sludge process, while under the Chemical Research Board investigations have ranged over the preparation of new chemotherapeutic products, the evaluation of antiseptics, the tendering of tarred cordage, immersed corrosion and chemical reactions at high pressure. The cause of persistent contamination of beer by a sulphurous odour has also been investigated and the trouble removed. The variety of bacteria which are responsible for the trouble has been isolated, and the infection has been traced to the cellar floors of the brewery.

The Radio Research Board has completed its studies of the ionosphere and of the propagation of waves along the ground and through the atmosphere, which have become of direct practical importance with the increased use of ultra-short rays for communication purposes. Other work has dealt with problems of direction finding. 
The Department has also been responsible for illumination research, including the daylight problems involved in illumination conditions in deep rooms and the standardization of lamps and fittings. Lubrication research carried out by the Department has included measurements of static friction, as well as work with the four-ball highpressure testing apparatus and on the physical properties of surfaces. Atmospheric pollution, the detection of toxic gases in industry, the development of a respirator for use in dust-laden atmospheres, $\mathrm{X}$-ray methods and measures conducive to greater safety in handling gas cylinders and containers have all come within the orbit of the Depart. ment.

The present report gives a most impressive picture not only of the way in which the work of the Department of Scientific and Industrial Research serves almost every aspect of everyday life no less than the needs of industry, but also of the admirable way in which its organization is adapted for co-operative work on the many problems that are brought before it by industry or by national needs.

\section{Marine Biology in South Africa}

\section{By Prof. R. S. Adamson and Prof. T. A. Stephenson, University of Cape Town}

$\mathrm{S}^{\mathrm{IN}}$ NCE 1932, an ecological survey of the South African coast has been in progress, carried out from the Departments of Botany and Zoology of the University of Cape Town. The survey is necessarily expensive, since it extends from Durban in the east to Port Nolloth in the west, covering a coastline between one and two thousand miles in length, parts of which are almost inaccessible. The expenses were defrayed, in the early stages, by the University of Cape Town and the South African Research Grant Board, with some private contributions; and assistance has also been received from the Royal Society of London. At the present time, expenses are being met from a generous grant made to the University by the Carnegie Corporation of New York.

The survey has been carried out by more than a dozen persons, but the principal contributions have been made by T. A. and Anne Stephenson, E. J. Eyre, G. F. Papenfuss and K. M. F. Bright. At present, thanks to the Carnegie grant, the survey employs three salaried research assistants and has been able to purchase a Chevrolet van for field-work.

The ecological results of the survey, up to the present, are being published in three periodicals. Accounts of specific areas on the coast have appeared during 1937-38 in the Transactions of the Royal Society of South Africa (24 and 25) and in the Annals of the Natal Museum (9). The first part of a general account of the results, as they affect the whole coast, is being published in the Journal of the Linnean Society of London (40). In addition to these papers by field-workers on the survey, systematic accounts have been published by specialists to whom collections, made in the course of the field-work, have been sent for identification. Altogether the survey has so far been responsible for the appearance of thirty-two papers, references to which will be found in the publications just mentioned.

Material collected during the survey and belonging to certain animal groups is identified by specialists on the staffs of the South African and Natal Museums, and many of the algæ are identified by Dr. Papenfuss, who is engaged upon a revision of the whole of the South African algæ; but the greater part of the material has to be sent to specialists at various European or American centres, notably the British Museum. Throughout the survey, steady support has been received from this circle of systematic workers, invaluable assistance without which the continuation of the investigation would have been impossible. Sincere thanks are offered not only to these systematists, but also to those who have assisted the survey by publishing results, and particularly to Dr. R. F. Lawrence of the Natal Museum. Duplicates of all collected material are retained at the University of Cape Town for future reference.

The survey has hitherto been confined to a study of the rocky parts of the intertidal belt. The scope and aims of the investigation are detailed in the first paper ${ }^{1}$ of the series mentioned above, but briefly it may be said to consist of three parts: (1) a general study of eight districts situated at intervals along the coast, from Port Nolloth in the west to Durban in the east; (2) a further study, at as many stations as possible, between the eight already mentioned; this section of the work to deal mainly with a selection of common organisms which have been shown by the eight primary surveys to be of particular importance ; and (3) a series of experimental studies designed to explain the observed distribution in the field of ecologically important 